\title{
Understanding Public Acceptance of a Multifunctional Water Plaza: A Case Study
}

\author{
Leon Netzel ${ }^{1, *}$, Emily Drewing ${ }^{2,3} \mathbb{C D}$, Louis Netzel $^{4}$ and Martin Denecke ${ }^{1}$ \\ 1 University of Duisburg-Essen, Urban Water and Waste Management, 45141 Essen, Germany; \\ martin.denecke@uni-due.de \\ 2 Department of Geography, Ruhr-University Bochum, 44799 Bochum, Germany; emily.drewing@rub.de \\ 3 Department of Social Science, Siegen University, 57068 Siegen, Germany \\ 4 Independent Researcher, 13353 Berlin, Germany; louisnetzel@web.de \\ * Correspondence: leon.netzel@uni-due.de
}

check for updates

Citation: Netzel, L.; Drewing, E.;

Netzel, L.; Denecke, M.

Understanding Public Acceptance of

a Multifunctional Water Plaza: A

Case Study. Water 2021, 13, 576.

https://doi.org/10.3390/w13040576

Academic Editors: Armando Di

Nardo and Enrico Creaco

Received: 6 January 2021

Accepted: 19 February 2021

Published: 23 February 2021

Publisher's Note: MDPI stays neutral with regard to jurisdictional claims in published maps and institutional affiliations.

Copyright: (c) 2021 by the authors. Licensee MDPI, Basel, Switzerland. This article is an open access article distributed under the terms and conditions of the Creative Commons Attribution (CC BY) license (https:/ / creativecommons.org/licenses/by/ $4.0 /)$.

\begin{abstract}
Climate change enhances pluvial flood risk in many cities all over the world, especially in densely populated urban areas with high impervious surfaces that need to adapt to heavy precipitation. For this purpose, multifunctional stormwater infrastructures such as water plazas appear promising as there is a high competition for open space in most urban areas. Yet, to date only very few water plazas have been realized with at least one implementation hampered by a lack of public acceptance. In this study, semi-structured interviews are used to investigate how plans to build a water plaza in the city of Cologne are perceived by local residents. Factors crucial to public acceptance are identified. Experience with flooding, knowledge of the planned construction and awareness of benefits turned out to be important for acceptance, whereas social and personal norms were less relevant. The identified factors led to finding recommendations to promote public acceptance of innovative climate adaptation measures like water plazas.
\end{abstract}

Keywords: public acceptance; water plaza; stormwater adaptation; climate change adaption; multifunctional infrastructure

\section{Introduction}

Climate change entails a range of profound challenges for cities all over the world. One of these is heavy precipitation with resulting pluvial flooding, which is expected to increase in many regions [1]. In urban areas, which are characterized by many impervious surfaces, pluvial water can cause flooding, stream erosion, destruction of aquatic habitats, and pollution of aquatic ecosystems by toxic loading input [2]. In Germany, the sewer systems are designed for stipulated "design" events that have prescribed return periods. According to [3], floods may occur on average every 20 years in residential areas so the sewer system is designed to capture rain events with a return period of 20 years. Events that exceed the "design" event lead to flooding. In the past, climate change and a possible increase in heavy precipitation events were not considered when sewer systems were being designed. An increase in the frequency and the extent of heavy precipitation events would shorten the return periods of events that exceed the "design" event and enhance the flood frequency. Today, the extension of underground sewerage systems is regarded as too expensive in many cases; therefore, new adaptation measures are needed to enhance resilience towards pluvial flooding.

At the same time, ongoing urbanization increases the number of city inhabitants and population density, reinforcing struggles over the use of scarce open spaces [4]. Against this backdrop, multifunctional areas which, among other things, can store stormwater, appear promising. Measures that enable a natural hydrological flow regime and improve water quality by pollutant reduction, are named differently depending on the geographical location [5]. The term "green infrastructure" is known as "low-impact development 
infrastructure" in North America, whereas "sustainable urban drainage systems" is used in the United Kingdom, "water-sensitive urban design" in Australia and "sponge city" in China [6]. Fletscher et al. [5] try to identify overlaps and differences among these terms, but they are often used synonymously. The aims of the measures are achieved by techniques that infiltrate, filter, evaporate, store and detain runoff close to its source [7]. Today, modelling techniques are valuable tools for finding the optimal design for measures designed to address the potential impacts of climate change $[6,8]$ and to assess the efficiency of these measures for runoff volume and peak flow reduction [8,9]. Palermo et al. [9] confirm the suitability of measures like permeable pavements and green rooftops for reducing surface runoff and urban flood risk. Nevertheless, the efficiency of flood risk reduction depends on the rainfall event in question. Effectiveness decreases with increasing rainfall, higher intensity and longer duration $[6,10]$. Some urban flood risk reduction measures like permeable pavements are additionally able to reduce the amount of dissolved metals (copper and zinc) and therefore make a contribution to water quality [7].

This study focuses on water plazas as measures to reduce urban flood risk. Usually, water plazas are attractive open urban spaces that serve as playgrounds or recreational areas. Only in the case of heavy precipitation do they turn into temporary water storage to alleviate strain on the drainage system [11,12]. The stored water comes from impermeable areas like roofs, parking areas or streets [13]. One example of a water plaza is the Benthemplein water plaza in Rotterdam, Netherlands. Next to their increased retention capacity, water plazas can serve an educative purpose by rendering water issues more visible and improving the quality of urban spaces [11]. Due to their multifunctional character, water plazas can be considered as no-regret adaptation measures as they ameliorate urban living environments even when their retention capacity is not used [4]. Nevertheless, there are only a few projects have been implemented to date [14-17].

In democratic societies, public acceptance plays a central role for the implementation of new technologies and infrastructures [18,19]. A lack of public acceptance can delay or even completely prevent construction [18]. For example, the first plans for a water plaza in Rotterdam had to be discarded due to a lack of public acceptance [11]. Therefore, gaining acceptance is one of the key issues when adopting sustainable systems [20]. A focus of contemporary acceptance research lies in renewable energy deployment, which shows that the transition towards renewable energy sources is generally perceived positively, whereas projects are often opposed locally $[20,21]$. In line with these findings, this study has investigated acceptance at the local level. Analyzing public acceptance of single projects is essential for balancing different stakeholder interests and addressing potential or existing conflicts [18]. As water plazas are very new adaptation measures that many people are not yet aware of, this study has focused on such a measure. In this vein, this study investigated how a planned water plaza in the city of Cologne was perceived by residents living in close proximity to the site. In addition, factors crucial to public acceptance were identified, and recommendations for promoting public acceptance of innovative climate adaptation measures (like water plazas) were derived.

\section{Methodology}

In the following, this study is briefly contextualized within the conceptual work on the acceptance of, as well as scarce empirical findings on, water plazas in urban settings.

\subsection{Acceptance Models}

The term acceptance is used in a variety of contexts, and its meaning differs accordingly [21]. In some cases, acceptance is equated with tolerance, indicating that there are no (publicly articulated) objections or protests $[20,22,23]$. Evidently, acceptance needs to be differentiated from acceptability. The latter term refers to a normative concept, indicating that a project is appropriate due to the rational consideration of quantifiable criteria $[21,24]$. In contrast, acceptance is subjective, relating to the tendency of individuals to welcome, or reject a certain project. In her acceptance model, Petra Schweizer-Ries [25] distinguished 
between two dimensions: valuation (positive or negative) and action (passive or active). According to her model, a positive valuation is essential for acceptance, irrespective of whether one becomes active or remains passive. For Cohen et al. [20], acceptance of new infrastructure is given when local residents feel at worst neutral or indifferent about its construction. In their concept, acceptance translates into a balance of aspects of increasing and decreasing local welfare, which needs to leave citizens at least as well off as they were before the project was realized. Based on Hofinger's [26] work, Sauer et al. [27] differentiate among eight levels of acceptance and non-acceptance (see adjusted Figure 1). This distinction was used in this study to assess public acceptance.

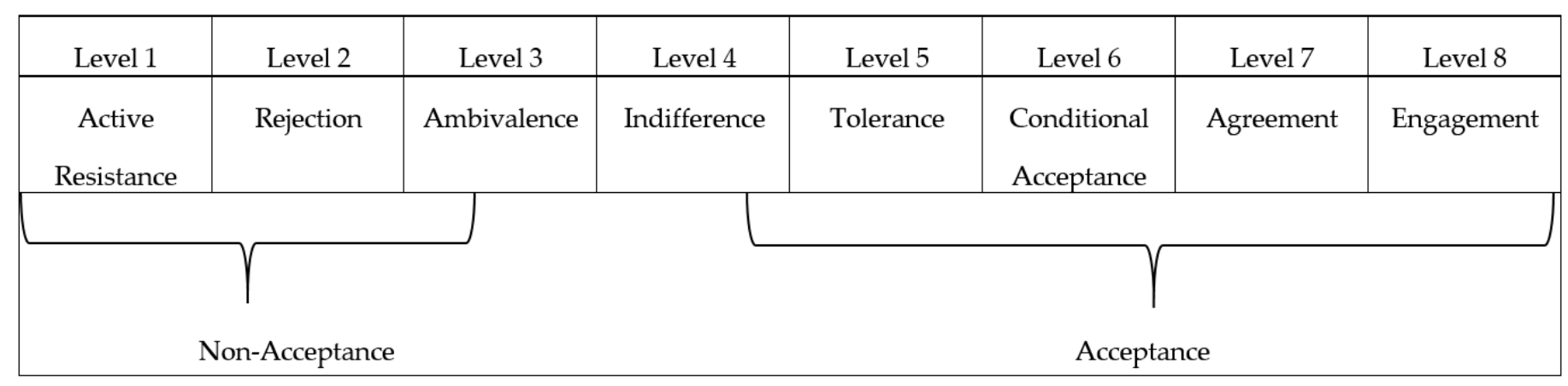

Figure 1. Acceptance levels based on Sauer et al. [16].

Furthermore, the model by Huits et al. [28] was used as a conceptual starting point to identify drivers of public acceptance. Figure 2 provides a schematic overview of the model. Here, the object of acceptance or rejection, respectively, is a water plaza, which was planned but not constructed at the time of study.

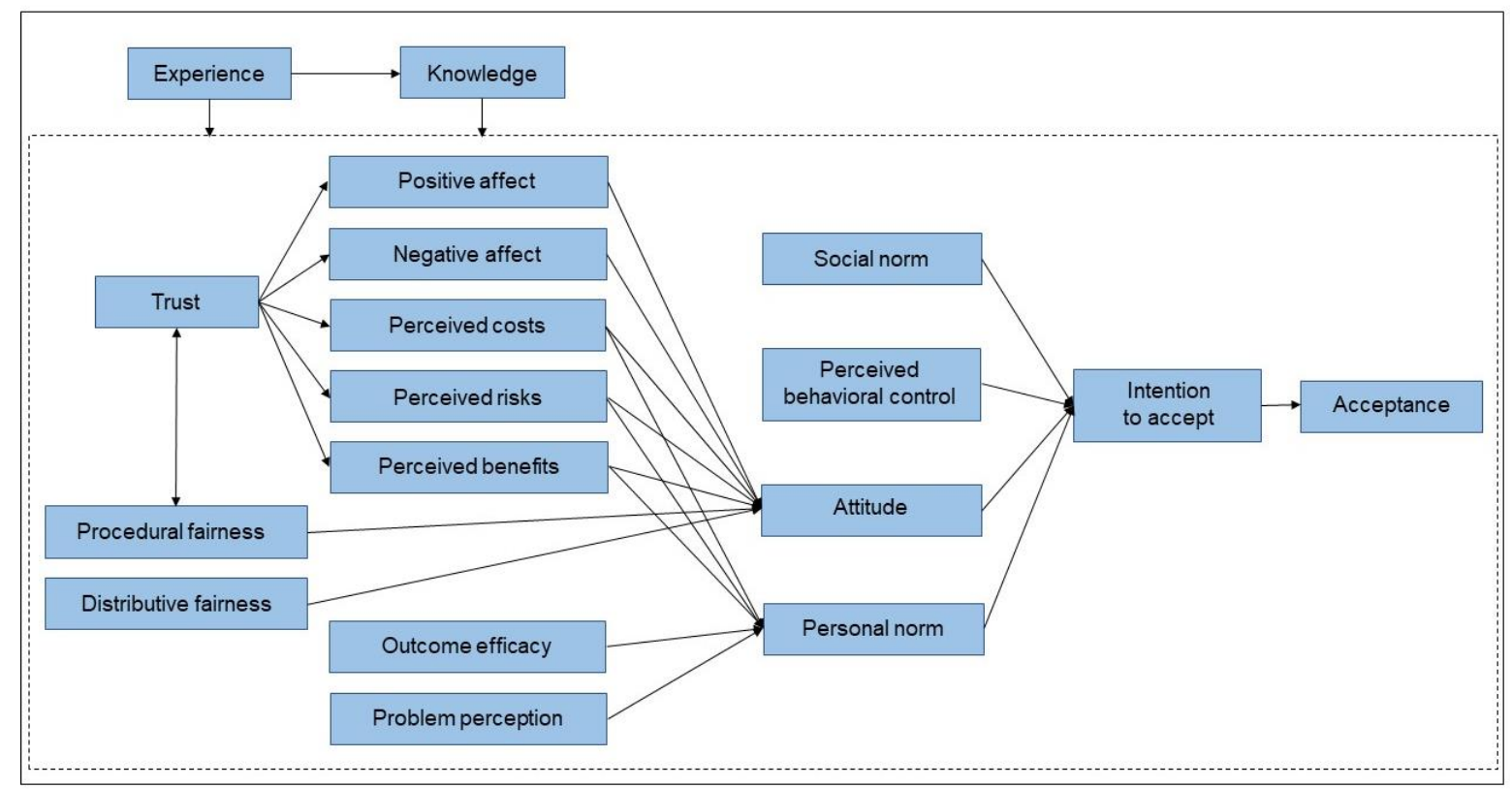

Figure 2. Schematic representation of the technology acceptance framework [17].

\subsection{Water Plazas as Urban Climate Adaption Measures}

Despite their advantages, there are hardly any climate adaptation measures realized in many cities [19,29]. In particular, there is a lack of multifunctional measures designed to manage future urban floods [14-17]. Water plazas are relatively new engineering concepts [13] that have attracted little scholarly attention to date. The multifunctionality of such spaces leads to a variety of aspects and interests that need to be considered [30], 
which leads to highly complex planning [29]. In order to successfully implement respective projects, broad public acceptance is essential [31]. The Benthemplein water plaza was completed in 2013, but the first attempts to build a water plaza in Rotterdam failed due to a lack of public acceptance [11]. Local citizens had concerns about the project's safety and health risks as, for instance, young children can easily drown in knee-high water [11]. Sales-Ortells and Medema [13] analyzed the health risks of the Benthemplein water plaza and the reported detrimental levels of bacteria concentration in stored water. Additionally, residents felt uneasy about a safe area turning into an unsafe environment rather abruptly. After conducting several participatory workshops, the project team had to admit that they could not overcome inhabitants' resistance. Therefore, they selected a different location in another neighborhood, adapted their participatory strategy and eventually realized the water plaza [11].

\subsection{Study Area}

The water plaza studied here is to be built in the German city of Cologne, which is home to about one million residents. In the district Eil (see Figure 3), a central plaza called Eiler Schützenplatz is to be reconstructed into a plaza built to capture stormwater in case of heavy precipitation. A hazard map for pluvial flooding, which has been available for free online since 2017 [32], shows flood-prone areas near the Eiler Schützenplatz. Figure 3 shows a dark-blue hotspot in the north of the plaza on a street called Kellereiweg and a large flood-prone area to the south. The transformation of the plaza should mainly reduce the flood risk along the Frankfurter Straße (street) to the south.

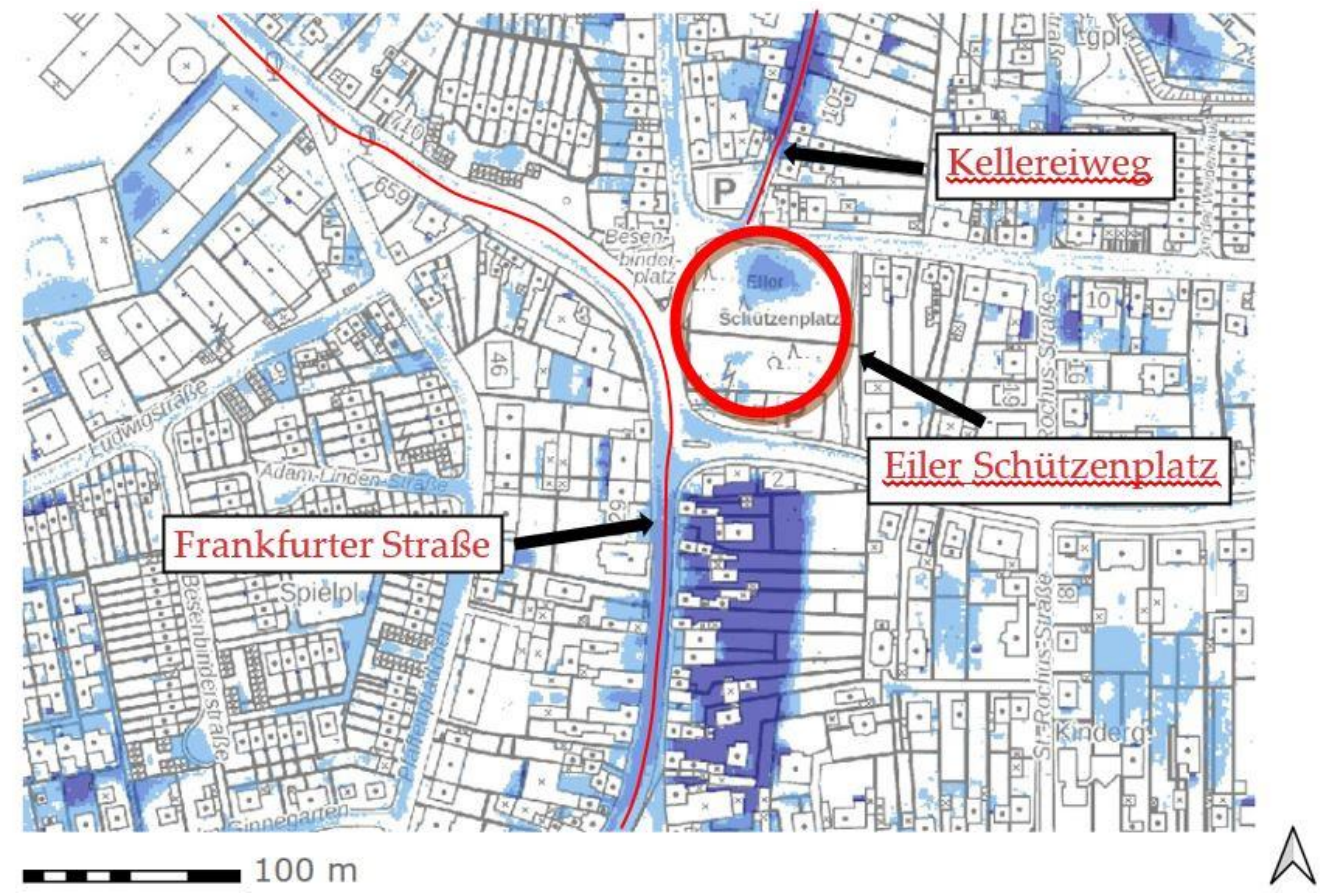

Figure 3. Hazard map for an extreme heavy precipitation event in the study area [33]. The darker the shade of blue, the higher the expected water depth and therefore the greater the risk of pluvial flooding. The red circle marks the site that will be transformed into a water plaza.

The area is drained by a combined sewer system. In case of a 100-year precipitation, the water depth would be up to $1.6 \mathrm{~m}$ in the southern hotspot [34]. In order to reduce flood risk, the Eiler Schützenplatz is to be separated into two parts. The northern part is slated to be a retention area, while the southern part will encompass a playground and parking area. Figure 4 shows the planned spatial arrangements of these different uses. 


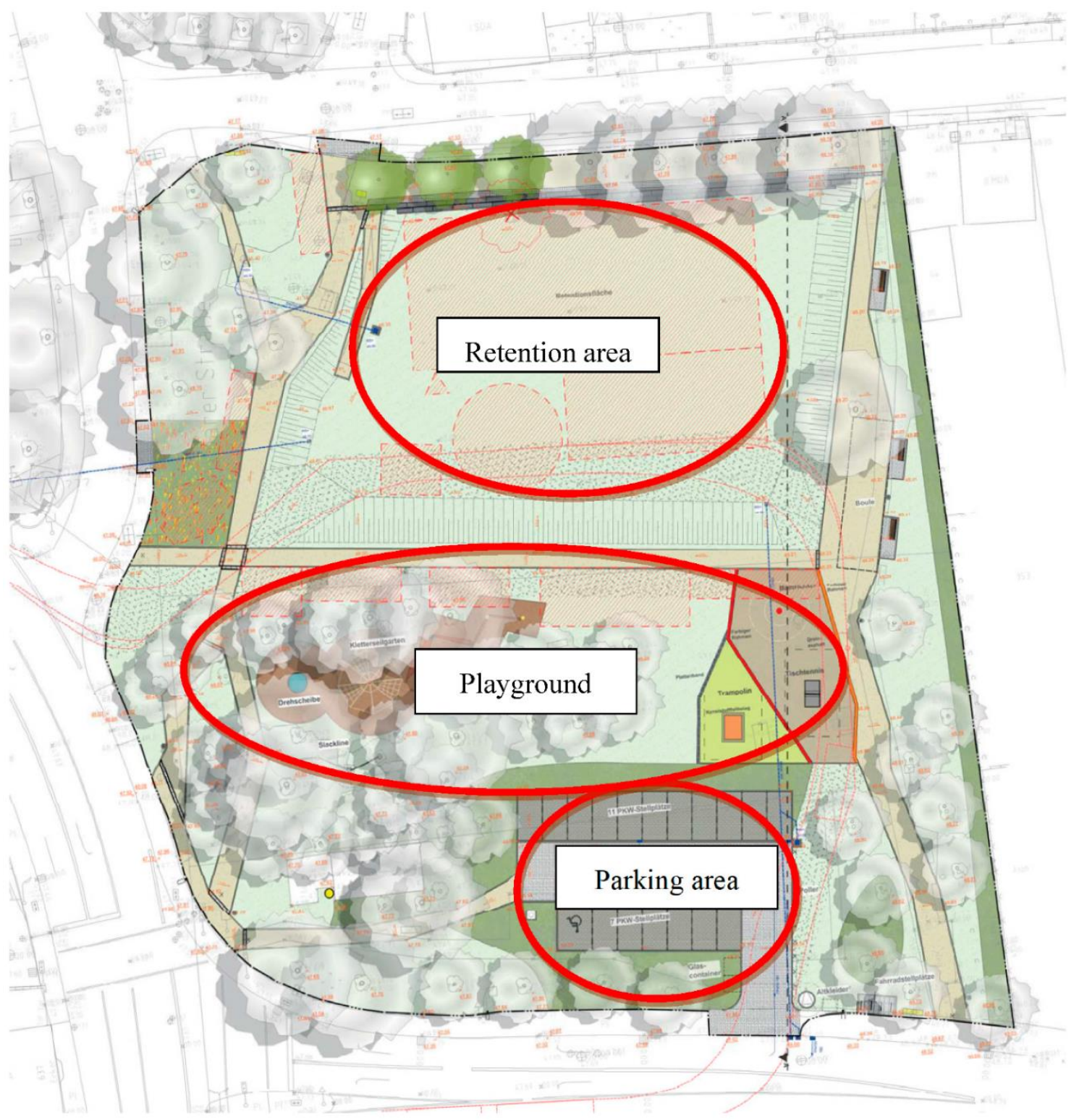

Figure 4. Planning design of the water plaza [35].

The retention area planned has an extent of $1940 \mathrm{~m}^{2}$, a maximum water depth of $0.65 \mathrm{~m}$ and a storage capacity of $471 \mathrm{~m}^{3}$ [36]. The area should only be flooded by events having return periods longer than five years. A detailed flood simulation by Henschel [34] revealed that based on the topography, the effective storage capacity would be $700 \mathrm{~m}^{3}$, leading to a maximum water depth of $86 \mathrm{~cm}$ in the retention area. The water plaza is intended to reduce the flood risk at the low point along Frankfurter Straße, but this low point receives water from many directions. Simulations of a 100-year rainfall event $(48.0 \mathrm{~mm}$ in $60 \mathrm{~min}$ as a block rain) revealed that just $15 \%$ of the water in the low point came from the northern part, where the retention area is located [34]. In case of a 100-year precipitation, the water plaza could reduce the water volume in the southern hotspot by $11 \%$ and lower the water depth by about $10 \mathrm{~cm}$, resulting in a maximum water depth of $1.5 \mathrm{~m}$ [34]. Henschel [34] concluded that the planned measures achieved a reduction in water volumes and water depths at the low point of Frankfurter Straße. Consequently, the risk of flooding can be reduced, albeit not eliminated completely. One of the reasons for this is that most of the water flows into the low point from other directions. Often many measures are needed to reduce pluvial flood risk through their cumulative effect. For example, green roofs or 
permeable pavements may hardly be able to reduce flood risk in a 100-year rainfall, but together with other measures like underground storage and multifunctional areas they can make an important contribution. Hua et al. [6] used modelling techniques to assess the performance of urban flood reduction measures. Their evaluation showed that the flood risk could be sufficiently reduced by using a combination of different measures, whereas single measures were less efficient. The planned water plaza is one measure even if it alone cannot capture all the water. In this paper, the focus is on the water plaza because it is a new concept with which the civilian population is not yet familiar.

\subsection{Data Collection and Analysis}

As acceptance is a complex construct influenced by a multitude of variables, a qualitative research design was chosen for this study. This was also well in line with water plazas being a niche phenomenon as some of the factors crucial to their acceptance may not yet be known. The acceptance model by Huits was taken as a starting point to develop interview guideline (see Table A1 in the Appendix A). The guideline was used to structure the interviews loosely as well as to maintain comparability. As usual in qualitative research, the questions were open, allowing the respondents to say what was important to them in relation to a subject. It was therefore possible for interviewees to pick up topics that would appear later in the guideline. To respond to these situations, there was no strict order of questions.

Also, some questions were added or adapted according to the interviewee, which was similar to the approach described by Friedl and Reichl [18]. After the questions about the interviewees' knowledge of the reconstruction, all people were informed about the plans in order to enable informed decisions further in the interview.

The interviews were conducted at the Eiler Schützenplatz. Most of the interview subjects were approached at the plaza or nearby because some lived in direct proximity. Each interview was audio recorded and transcribed. The transcripts were thematically coded [37]. First, a coding catalogue was derived from the interview guideline. During the coding process, new categories emerged, which is common in qualitative social research as well as in line with Friedl and Reichl's [18] findings. The interviewees' statements assigned to the categories were merged and condensed to obtain an overview of the topics covered. As shown in Figure 5, types were developed by grouping interviewees with similar acceptance levels. This allowed for scrutiny of commonalities, which possibly bears investigating to understand individual acceptance. In addition, the statements assigned to each category were analyzed separately.

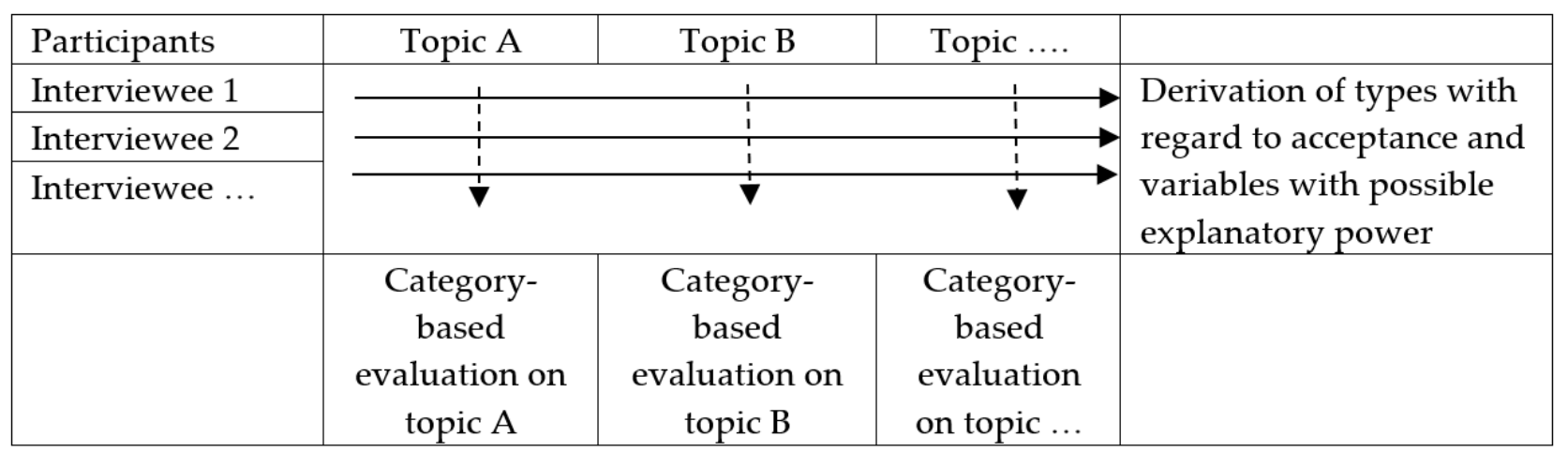

Figure 5. Schematic representation of the data analysis.

\section{Results}

In all, 19 interviews were completely transcribed. One interviewee's acceptance of the planned water plaza could not be determined, as this person was reluctant to share respective information. Based on the interview data, the 18 respondents were assigned to five types of acceptance or non-acceptance. Specifically, two were assigned to 
"Engagement", seven to "Agreement", four to "Indifference", three to "Ambivalence" and two to "Rejection".

\subsection{Factors Crucial to Public Acceptance of Multifunctional Urban Stormwater Infrastructure}

The acceptance model by Huijts et al. [28] serves as a starting point for the analysis of key drivers of public acceptance for water plazas. The categories identified by Huijts et al. [28] were modified and aggregated for this study.

3.1.1. Locals Experience with Heavy Precipitation, Their Knowledge and Perception of the Construction

All participants had already experienced heavy precipitation. However, some of the respondents were not sure what exactly that was. Four had suffered damage from heavy rain. Two interviewees reported having their basement flooded with rainwater, but no damage was caused. Most respondents had not suffered any damage until the time they were interviewed.

Most respondents knew that a reconstruction of the Eiler Schützenplatz was being planned. Six interviewees lived directly at the plaza and heard about the reconstruction plans. However, respondents differed in their knowledge of details. Some were aware of the planning of the retention area while others knew about the installation of play equipment. The two best-informed interviewees had attended a public participation event. Sources of information were diverse. Two respondents saw a television report. A few read about the project in a local newspaper, while others learned about the planned reconstruction from neighbors. Seven people were unaware of the planned renovations. Officially, the Eiler Schützenplatz is a playground. However, due to limited and sometimes broken play equipment, the playground was often not recognized as a such. Currently, the Eiler Schützenplatz is mainly used as a dog meadow, where dogs play and do their business. It also serves as a venue for local celebrations and events. The maintenance of the site was criticized by some: according to two respondents, littering is a common issue. Of the people surveyed, seven used the plaza to walk dogs. Many interviewees hardly frequented the plaza or only did so at events. In addition, some respondents regularly used the seating.

\subsubsection{Flood Risk Perception and Efficacy Assessment}

Ten of the participants expected an increase in the frequency of heavy rain events in Cologne and in Germany in general. Only one respondent perceived a decrease and therefore expected fewer heavy precipitation events in the future. Three interviewees felt unable to assess the future development of heavy rain frequency. Most respondents had not observed any issues in the vicinity of the plaza after heavy precipitation while some noticed problems in the Kellereiweg, which had been flooded several times. None of the people interviewed mentioned a risk of flooding along Frankfurter Straße, the largest hotspot whose flood risk will be mitigated by the retention area. Not surprisingly, assumed outcome efficacy was closely related to problem perception. Some people did not perceive heavy precipitation as a (future) threat; therefore, in their view, the planned construction of a retention area did not make sense. A few interviewees reported that they had witnessed flood-related problems in the Kellereiweg; however, a resident living there did not expect a direct improvement of flood protection through the planned retention area. Some participants pointed out that they were not experts and did not have the necessary information to adequately assess how much rainwater falls in the catchment area, how much can be stored, how much the construction will cost and which benefits can realistically be expected after construction is completed.

\subsubsection{Perceived Advantages, Disadvantages and Risks}

Nevertheless, the respondents assumed there were advantages, disadvantages and risks to the conversion. Many participants were concerned about the site's adequacy as a venue for festive events after the reconstruction. One interviewee feared the emergence 
of a social flashpoint; two saw a risk of increased littering; three were worried about the storage capacity; and one person was concerned that rainwater may run to the Kellereiweg if the basin's capacity were exceeded. During construction, road closures, construction noise, dust and vibrations are expected, which the interviewees found tolerable. In case of the water storage being in use, some feared an increased risk of personal injury, especially for toddlers who may drown even in shallow water. However, the risk of accidents was considered to be low, as water would only be stored very rarely, and parents are deemed responsible for supervising their young children. The setup of play equipment and thus increased attractiveness for children is seen as a benefit. Furthermore, the attractiveness of the site is expected to grow through the addition of flowerbeds and benches. The planned water and electricity connection was welcomed by local associations. Additionally, the intended levelling of the square is expected to facilitate setting up marquees. The main advantage of redesigning the plaza is seen in increased flood protection for residents. Yet respondents were unable to specify which houses would be protected: some assumed primary protection of the Kellereiweg, but others believe in improved protection of the entire district and the relief of local drainage systems. Three interviewees saw no benefits in the redesign.

\subsubsection{Social and Personal Norms}

In the literature, social and personal norms are often reported as drivers for public acceptance. However, most interviewees did not report any social pressure regarding the acceptance of the retention area. Some added that the issue had no relevance for them or their social environment. Only one person perceives a social norm. Furthermore, the respondents who commented on this subject stated that they neither had a personal norm nor acted according to one. Thus, participants did not feel a moral obligation to reject or accept the planned construction work.

\subsubsection{Perceived Responsibility of Flood Protection and Trust in Those Responsible}

The responsibility for pluvial flood protection was, on the one hand, seen to lie with public administrations such as the city of Cologne, the state of North Rhine-Westphalia or urban drainage companies. On the other hand, citizens were seen as sharing responsibility. In particular, homeowners and landlords were deemed responsible for taking measures to prevent pluvial flooding. The reported trust in the relevant institutions varied among the respondents. One interviewee felt unable to assess their trust because the interviewee had never been in contact with the relevant institutions. The majority of participants trusts the city of Cologne to protect them from pluvial flooding, while one had limited trust and another respondent had no trust in the municipality.

\subsubsection{Public Participation and Perceived Influences}

The possibilities of influencing the project were perceived very differently. Two respondents did not believe that the (affected) population could actually influence public projects in general. Many interviewees assumed that individuals cannot exert decisive influence on such projects, while larger groups of people were more likely able to do so. However, five participants assumed that citizens were influential or had already influenced public decisions themselves. Due to a migration background and linguistic problems, one respondent found it difficult to become active while others remained passive as they were simply not interested in getting involved. One interviewee reported that the lawful procedure, which needed to be followed when lodging a complaint, hampered the person from becoming active. For some interviewees, taking action (e.g., initiating petitions and demonstrations) would reportedly have been easy. Still, most interviewees had no knowledge of the public participation event although some would not have wanted to participate even if they had known about it. One respondent would have liked to be informed by means of a personal letter on both the participation event and the reconstruction plans, whereas another, who was actually informed about the event, was not interested in attending. Two 
interviewees were unable to attend the event because they had other appointments. The two respondents who attended the public participation event noted how they were able to actively codetermine the plans. They estimated that about 20-40 participants attended, which they both considered as rather few. The event itself was assessed very positively (provided that the participants' suggestions were implemented, which appeared to be intended whenever possible). Since construction measures had not yet started, it was difficult to assess the fairness of the process. Respondents who were not involved in the public participation event found it difficult to judge it. However, two of them assumed the process to be fair. The two interviewees who participated were positive about the process so far.

\subsection{Five Types of Acceptance and Non-Acceptance of Multifunctional Urban Stormwater Infrastructure}

Two interviewees rejected the plans and were therefore assigned to the "Rejection" type. Their reasons for disapproval differed considerably. Interviewee 6 rejected the water plaza for fear of detrimental effects to nature. The other respondent (interviewee 18) assigned to this type currently rates the construction project positively and believes that a tolerable underground basin will be built. However, said interviewee objected to an open space solution (as is planned), because of the threat it might pose to children. Thus, the positive attitude towards the project was due to insufficient knowledge of the construction plans. At the time of the interviews, both interviewees had not suffered any damage from heavy precipitation themselves, had not noticed any heavy rain-indicated flooding problems in the vicinity of the Eiler Schützenplatz and will hardly be affected by the construction measures.

Respondents who expressed a certain degree of ambivalence regarding their support (or disapproval) of the plans were assigned to the "Ambivalence" type. Two of the three interviewees included here (interviewees 1 and 10) gave relatively similar statements questioning the usefulness of the conversion since an underground basin already exists under the Eiler Schützenplatz. So far, neither of the two has experienced any damage from heavy rain. Although they have lived in the area for a long time, they had not observed any flooding, except for events in the Kellereiweg. In addition, both felt unable to estimate how heavy precipitation would develop in the future. Possibly due to a lack of problem awareness, they questioned the benefits of the retention area and stated that the public funds would be of greater use elsewhere. Nevertheless, the use of the Eiler Schützenplatz as a water plaza was seen as unproblematic and the risk of accidents rated as low. Both are residents who use the plaza daily and criticized the municipality's poor maintenance of the place. In general, their trust in public institutions is limited and they were unaware of possibilities to influence such projects. Additionally, interviewee 15 was assigned to this type. Before the interview, this respondent had never dealt with heavy precipitation and thus lacked understanding of the retention area at first. Also, said interviewee was often rather elusive, frequently reflecting other people's (assumed) views on the topics covered instead of describing a personal one. Consequently, the interviewee underlined both positive and negative aspects of the conversion, expressing an ambivalent opinion on the subject.

The "Indifference" type encompasses four interviewees who reported that they did not care about the planned reconstruction. All of them had experienced heavy precipitation before, but they have not suffered any damage so far. Two interviewees use the space to walk their dogs while for the others it serves as recreational area. Three respondents did not observe any flooding issues in the vicinity of the plaza. One interviewee reported a such problem occurring in the Kellereiweg, yet saw no benefits in the planned retention basin. Two respondents believed it will provide better flood protection for residents without being able to specify which houses would be protected. Prior to its mention by the interviewer, none of the interviewees was aware of the planned retention basin.

All respondents of the "Agreement" type rated the retention basin positively. Five of seven had already suffered damage from water entering their buildings after heavy 
precipitation or at least witnessed it. Only three people realized rain-related problems in the vicinity of the Eiler Schützenplatz. All but one of the seven interviewees assigned to this type expected a future increase in the frequency of heavy precipitation events in Germany and Cologne in particular. Five knew about the planned reconstruction measures. While they reported a multitude of risks and disadvantages, all the respective respondents perceived the improved flood protection as an advantage.

The "Engagement" type consists of two interviewees who took part in the single public participation event. Thus, attendance of said event was considered as an active behavior here. The respondents expected no or hardly any disadvantages or risks due to the construction of the retention basin. In addition to the improved flood protection, a variety of advantages were reported such as the installation of a water and electricity connection, the mounting of play equipment for children, the increased navigability of the place (e.g., convenient for the pitching of festival marquees) and the levelling of the place. The interviewees were very well informed about the proposed measure although they could not assess the effectiveness of the water plaza, as this is reserved for experts. Floodrelated problems were mainly reported for the Kellereiweg. The respondents felt that the public can actually exert an influence on the project. Correspondingly, they evaluated the public participation event very positively, provided that the suggestions of the population were taken into account.

\section{Discussion}

The focus of this study was on the Eiler Schützenplatz, which is officially a playground but actually serves more as a dog meadow due to the lack of play equipment. In general, the place currently is of low quality. The empirical inquiry was conducted at a time when detailed planning had not yet been fully completed, but the project had already been decided upon by all councils. There was no protest at the time of the interviews. Following the definition of acceptance by Schweizer-Ries [25], 9 out of 18 interviewees gave a positive assessment of the planned project and therefore accepted it. The differentiation of the acceptance characteristics according to Sauer et al. [27] enables a group of persons with similar acceptance levels and the identification of similarities.

The conceptual starting point of this inquiry was the acceptance model by Huijts et al. [28], which was originally developed to measure acceptance for renewable energies. Here, the model was used to assess acceptance for an innovative water storage project, as no acceptance models had been established in this research field to date. The empirical findings presented in Section 3.1 showed that some aspects included in the model had no relevance for the planned retention area at the Eiler Schützenplatz. For example, social norms and personal norms-two important components of the model by Huijts et al. [28] - appeared negligible for the locals' acceptance of the water plaza. This was possible since heavy precipitation and pluvial flood protection have hardly been of interest to many people. In addition, there was no manifest conflict, and many respondents hardly felt affected by the reconstruction. Other factors included in the model by Huijts et al. [28], such as perceived costs or outcome efficacy, could not be assessed by the interviewees. In general, dealing with uncertainties (for instance, future local development of precipitation and the effectiveness of respective adaptation measures like water plazas) was challenging [4].

Aggregating several types of acceptance and scrutinizing respective respondents characteristics as shown in Section 3.2 allowed for new insights into the acceptance of water plazas. For instance, interviewees who did not accept the measure or who were indifferent towards it had not yet suffered any damage from pluvial flooding. On the other hand, among the respondents showing high levels of acceptance many had already suffered damage from pluvial flooding. Similar findings were reported by Gabe et al. [2]. After studying rainwater harvesting systems, they found that personal experience can influence acceptance. Moreover, the vast majority of interviewees accepting the measure expected heavy precipitation events to increase, while participants who were more critical about 
the project did not expect heavy precipitation to become a future issue. Some respondents reported the Kellereiweg as a flood-prone area, which is in line with the heavy precipitation hazard map (see Figure 3). None of them, however, mentioned the main hotspot along Frankfurter Straße. Most interviewees who noted the Kellereiweg as an area in danger of pluvial flooding deemed the project acceptable.

The perception of the measure as being advantageous is closely linked to whether or not one considered heavy precipitation a (future) problem. Benefits were perceived almost exclusively by people who felt positive about the planned reconstruction. Thus, all respondents of the "Agreement" type note improved flood protection as an advantage. Some disadvantages and risks were assumed, but these were mainly assessed as low and acceptable. The interviewees who had attended the public participation event held extensive knowledge on the reconstruction and mentioned many advantages of which the other respondents were not aware. Hence, knowledge appears crucial in relation to widely unknown measures [38], such as multifunctional retention areas. The importance of knowledge for public acceptance was also highlighted by Bertsch et al. [21] and Dhakal and Chevalier [19].

\section{Recommendations}

The low attractiveness and limited use of the existing plaza are likely encouraging the acceptance of the project. For other places, such as parking lots or sports fields, plans to turn these areas into multifunctional retention areas may encounter fiercer resistance. The results of this study showed that providing broad information to the local population is crucial for a positive public attitude towards water management projects. It is recommended that residents receive personal letters or e-mail to inform them about the plans and possibilities for codetermination and participation, as well as viable sources to gather additional information on the project. Specifically, pending and future issues and risks must be communicated comprehensively in order to convey the purpose of the planned measures and their benefits. Similar recommendations were made by Friedl and Reichl [18] for energy infrastructure. The need to communicate benefits effectively was underlined by respondents of the "Ambivalence" type: they did not hold a negative attitude toward the retention area but questioned its usefulness and necessity because they had been insufficiently informed about the risks and benefits.

Regarding the transfer of knowledge, using easy-to-understand language is crucial as heavy precipitation events and pluvial flood protection are topics still unfamiliar to many people. The participation event showed that such formats are suitable to impart knowledge. Nevertheless, many respondents did not take notice of the participation event. Thus, such formats should be promoted intensively in order to achieve a larger (and, ideally, more diverse) number of participants. In line with this, Kuller et al. [29] and Röschel et al. [39] conclude that planned adaptation measures should include the preferences and interests of the (local) population. The results presented here underline these recommendations.

Finally, it should be noted that even extensive information and participation of the population can never guarantee public acceptance (Friedl and Reichl [18]). Furthermore, acceptance is a dynamic construct that cannot be achieved once and maintained constantly throughout the construction process. Therefore, a strategy for communication and participation that is both comprehensive and reflexive along the trajectory appears most promising, albeit most intricate, too.

Author Contributions: Conceptualization, L.N. (Leon Netzel), E.D., L.N. (Louis Netzel) and M.D.; methodology, L.N. (Leon Netzel) and E.D.; software, L.N. (Leon Netzel) and L.N. (Louis Netzel), validation, L.N. (Leon Netzel), E.D. and L.N. (Louis Netzel); formal analysis, L.N. (Leon Netzel); investigation, L.N. (Leon Netzel); resources, L.N. (Leon Netzel) and E.D.; data curation, L.N. (Leon Netzel) and L.N. (Louis Netzel); writing — original draft preparation, L.N. (Leon Netzel); writingreview and editing, E.D., L.N. (Louis Netzel) and M.D.; visualization, L.N. (Leon Netzel); supervision, M.D.; project administration, L.N. (Leon Netzel). All authors have read and agreed to the published version of the manuscript. 
Funding: The APC was funded by the University of Duisburg-Essen.

Institutional Review Board Statement: Ethical review and approval were waived for this study, due to the study not being medical research (to which the Declaration of Helsinki applies). However, the study is well in line with the principles of the Safeguarding of Good Scientific Practice at the University of Duisburg-Essen (https:/ / www.uni-due.de/en/research_good_scientific_practice.php) and the rules of good scientific practice as issued by the German Research Foundation (Deutsche Forschungsgemeinschaft, DFG; https://www.dfg.de/en/research_funding/principles_dfg_funding/good_ scientific_practice/).

Informed Consent Statement: Informed consent was obtained from all subjects involved in the study. Also, the results are presented in a way that does not allow to identify the respondents, as personal information are not provided.

Data Availability Statement: The data presented in this study are available on request from the corresponding author. The data are not publicly available due to privacy reasons. The recorded interviews would possibly allow conclusions to be drawn about a person's identity.

Conflicts of Interest: The authors declare no conflict of interest.

\section{Appendix A}

Table A1. Translated interview guideline.

\begin{tabular}{|c|c|}
\hline Category & Questions \\
\hline Interest & $\begin{array}{l}\text { Are you interested in the topic of heavy } \\
\text { precipitation? }\end{array}$ \\
\hline Experience & $\begin{array}{l}\text { Have you ever experienced heavy rain? } \\
\text { Did you suffer any damage as a result? }\end{array}$ \\
\hline Risk and problem perception & $\begin{array}{l}\text { What do you think: How will heavy } \\
\text { precipitation events develop in the future? } \\
\text { Do you think heavy precipitation events are } \\
\text { going to be a problem in future? } \\
\text { Do you know the heavy precipitation hazard } \\
\text { map? } \\
\text { Have you ever heard of problems after heavy } \\
\text { precipitation here in the neighborhood? }\end{array}$ \\
\hline Responsibility & $\begin{array}{l}\text { Who do you think is responsible for pluvial } \\
\text { flood protection? } \\
\text { Do you have any responsibility yourself? }\end{array}$ \\
\hline Trust & $\begin{array}{l}\text { To what extent do you trust these institutions } \\
\text { (to adequately protect you against pluvial } \\
\text { flooding)? }\end{array}$ \\
\hline $\begin{array}{l}\text { Current state of the Eiler Schützenplatz and } \\
\text { usage }\end{array}$ & How do you normally use the park? \\
\hline Knowledge & $\begin{array}{l}\text { Do you know about a planned reconstruction } \\
\text { of this park? } \\
\text { What is planned here? }\end{array}$ \\
\hline Acceptance & $\begin{array}{l}\text { How do you assess the use of this area for } \\
\text { water storage after heavy precipitation? } \\
\text { Would you like to prevent the implementation? }\end{array}$ \\
\hline Advantages & $\begin{array}{l}\text { What are the advantages of such a use? } \\
\text { Who benefits from the redesign? }\end{array}$ \\
\hline
\end{tabular}


Table A1. Cont.

\begin{tabular}{ll}
\hline \multicolumn{1}{c}{ Category } & \multicolumn{1}{c}{ Questions } \\
\hline Disadvantages \& Risks & $\begin{array}{l}\text { Do you think there are any risks? } \\
\text { What are the disadvantages of such use? }\end{array}$ \\
\hline \multirow{2}{*}{ Outcome-Efficacy } & $\begin{array}{l}\text { Do you think that this form of use can } \\
\text { contribute to the effective solution of the flood } \\
\text { problem? }\end{array}$ \\
\hline Costs and distributional fairness & $\begin{array}{l}\text { How would you assess the costs? } \\
\text { How do you assess the distribution of } \\
\text { costs/benefits /risks? }\end{array}$ \\
\hline Is the distribution fair in your opinion?
\end{tabular}

\section{References}

1. IPCC. Climate Change 2014: Synthesis Report. Contribution of Working Groups I, II and III to the Fifth Assessment Report of the Intergovernmental Panel on Climate Change; IPCC: Geneva, Switzerland, 2014.

2. Gabe, J.; Trowsdale, S.; Mistry, D. Mandatory urban rainwater harvesting: Learning from experience. Water Sci. Technol. 2012, 65, 1200-1207. [CrossRef] [PubMed]

3. DWA-M 119. In Risikomanagement in der Kommunalen Überflutungsvorsorge für Entwässerungssysteme bei Starkregen, [Translation: Risk management in Municipal Flood Prevention for Drainage Systems in the Event of Heavy Precipitation]; Deutsche Vereinigung für Wasserwirtschaft, Abwasser und Abfall: Hennef, Germany, 2016; ISBN 978-3-88721-392-3.

4. Mees, H.; Driessem, P.P.J. Adaptation to climate change in urban areas: Climate-greening London, Rotterdam, and Toronto. Clim. Law 2011, 2, 251-280. [CrossRef]

5. $\quad$ Fletcher, T.D.; Shuster, W.; Hunt, W.F.; Ashley, R.; Butler, D.; Arthur, S.; Trowsdale, S.; Barraud, S.; Semadeni-Davies, A.; BertrandKrajewski, J.-L.; et al. SUDS, LID, BMPs, WSUD and more-The evolution and application of terminology surrounding urban drainage. Urban Water J. 2015, 12, 525-542. [CrossRef]

6. Hua, P.; Yang, W.; Qi, X.; Jiang, S.; Xie, J.; Gu, X.; Li, H.; Zhang, J.; Krebs, P. Evaluating the effect of urban flooding reduction strategies in response to design rainfall and low impact development. J. Clean. Prod. 2020, 242, 118515. [CrossRef]

7. Turco, M.; Brunetti, G.; Palermo, S.A.; Capano, G.; Grossi, G.; Maiolo, M.; Piro, P. On the environmental benefits of a permeable pavement: Metals potential removal efficiency and Life Cycle Assessment. Urban Water J. 2020, 17, 619-627. [CrossRef]

8. Ghodsi, S.H.; Zahmatkesh, Z.; Goharian, E.; Kerachian, R.; Zhu, Z. Optimal design of low impact development practices in response to climate change. J. Hydrol. 2020, 580, 124266. [CrossRef]

9. Palermo, S.A.; Talarico, V.C.; Turco, M. On the LID systems effectiveness for urban stormwater management: Case study in Southern Italy. IOP Conf. Ser. Earth Environ. Sci. 2020, 410, 12012. [CrossRef]

10. Lin, J.-Y.; Yuan, T.-C.; Chen, C.-F. Water Retention Performance at Low-Impact Development (LID) Field Sites in Taipei, Taiwan. Sustainability 2021, 13, 759. [CrossRef] 
11. Biesbroek, G.R.; Termeer, C.J.A.M.; Klostermann, J.E.M.; Kabat, P. Rethinking barriers to adaptation: Mechanism-based explanation of impasses in the governance of an innovative adaptation measure. Glob. Environ. Chang. 2014, 26, 108-118. [CrossRef]

12. Dircke, P.; Molenaar, A. Climate change adaptation; innovative tools and strategies in Delta City Rotterdam. Water Pract. Technol. 2015, 10, 674-680. [CrossRef]

13. Sales-Ortells, H.; Medema, G. Microbial health risks associated with exposure to stormwater in a water plaza. Water Res. 2015, 74, 34-46. [CrossRef] [PubMed]

14. Benden, J. Multifunktionale Flächennutzung als Beitrag zur urbanen Starkregenvorsorge [Translation: Multifunctional areas as a contribution to urban heavy precipitation precaution]. Korresp. Abwasser Abfall 2015, 62, 130-137.

15. Benden, J.; Broesi, R.; Illgen, M.; Leinweber, U.; Lennartz, G.; Scheid, C.; Schmitt, T.G. Multifunktionale Retentionsflächen. Teil 3: Arbeitshilfe für Planung, Umsetzung und Betrieb [Translation: Multifunctional Retention Areas. Part 3: Working Aid for Planning, Implementation and Operation]. MURIEL Publikation. Available online: https://www.dbu.de/OPAC/ab/DBUAbschlussbericht-AZ-32223_03.pdf, (accessed on 23 February 2021).

16. Illgen, M.; Leinweber, U.; Benden, J.; Broesi, R.; Scheid, C.; Schmitt, T.G.; Lennartz, G. Multifunktionale urbane Retentionsräume: Ergebnisse und Erkenntnisse aus dem praxisorientierten Forschungsprojekt MURIEL [Translation: Multifunctional urban retention areas: Results and findings from the practice-oriented research project MURIEL]. Korresp. Wasserwirtsch. 2018, 11, 94-99.

17. Kind, C.; Kaiser, T.; Riese, M.; Bubeck, P.; Müggenburg, E.; Thieken, A.; Schüller, L.; Fleischmann, M. Vorsorge Gegen Starkregenereignisse und Maßnahmen zur Wassersensiblen Stadtentwicklung-Analyse des Standes der Starkregenvorsorge in Deutschland und Ableitung zukünftigen Handlungsbedarfs [Translation: Precautions against Heavy Precipitation Events and Measures for Water-Sensitive Urban Development-Analysis of the Status of Heavy Precipitation Precautions in Germany and Derivation of Future Need for Action]; Umweltbundesamtes: Dessau-Roßlau, Germany, 2019.

18. Friedl, C.; Reichl, J. Realizing energy infrastructure projects-A qualitative empirical analysis of local practices to address social acceptance. Energy Policy 2016, 89, 184-193. [CrossRef]

19. Dhakal, K.P.; Chevalier, L.R. Managing urban stormwater for urban sustainability: Barriers and policy solutions for green infrastructure application. J. Environ. Manage. 2017, 203, 171-181. [CrossRef] [PubMed]

20. Cohen, J.J.; Reichl, J.; Schmidthaler, M. Re-focussing research efforts on the public acceptance of energy infrastructure: A critical review. Energy 2014, 76, 4-9. [CrossRef]

21. Bertsch, V.; Hall, M.; Weinhardt, C.; Fichtner, W. Public acceptance and preferences related to renewable energy and grid expansion policy: Empirical insights for Germany. Energy 2016, 114, 465-477. [CrossRef]

22. Acatech. Akzeptanz von Technik und Infrastrukturen, [Translation: Acceptance of Technology and Infrastructures]; Springer: Berlin/Heidelberg, Germany, 2011; ISBN 978-3-642-20743-3.

23. Schäfer, M.; Keppler, D. Modelle der technikorientieren Akzeptanzforschung: Überblick und Reflexion am Beispiel eines Forschungsprojekts zur Implementierung Innovativer Technischer Energieeffizienz-Maßnahmen, [Translation: Models of Technology-Oriented Acceptance Research. Overview and Reflection Using the Example of a Research Project for the Implementation of Innovative Technical Energy Efficiency Measures]. Discussion Paper No. 34. 2013. Available online: http: //www.tu-berlin.de/ztg/menue/publikationen/discussion_papers/ (accessed on 3 April 2018).

24. Lucke, D. Akzeptanz: Legitimität in der, Abstimmungsgesellschaft [Translation: Acceptance. Legitimacy in the Voting Society]; VS Verlag für Sozialwissenschaften: Wiesbaden, Germany, 1995; ISBN 978-3-8100-1496-2.

25. Schweizer-Ries, P. Energy sustainable communities: Environmental psychological investigations. Energy Policy 2008, 36, 4126-4135. [CrossRef]

26. Hofinger, G. Denken über Umwelt und Natur, [Translation: Thinking about the Environment and Nature], 1. Aufl.; Beltz, PVU: Weinheim, Germany, 2001; ISBN 978-3621275057.

27. Sauer, A.; Frieder, L.; Suda, M.; Weiland, U. Steigerung der Akzeptanz von FFH-Gebieten, [Translation: Increasing the acceptance of FFH areas.]. BfN-Skripten. 2005. Available online: https://www.bfn.de/fileadmin/BfN/service/Dokumente/skripten/ Skript144.pdf (accessed on 23 February 2021).

28. Huijts, N.M.A.; Molin, E.J.E.; Steg, L. Psychological factors influencing sustainable energy technology acceptance: A review-based comprehensive framework. Renew. Sustain. Energy Rev. 2012, 16, 525-531. [CrossRef]

29. Kuller, M.; Farrelly, M.; Deletic, A.; Bach, P.M. Building effective Planning Support Systems for green urban water infrastructurePractitioners' perceptions. Environ. Sci. Policy 2018, 89, 153-162. [CrossRef]

30. Roovers, G.J.; van Buuren, M.W. Stakeholder participation in long term planning of water infrastructure. Infrastruct. Complex 2016, 3, 216. [CrossRef]

31. Venkataramanan, V.; Packman, A.I.; Peters, D.R.; Lopez, D.; McCuskey, D.J.; McDonald, R.I.; Miller, W.M.; Young, S.L. A systematic review of the human health and social well-being outcomes of green infrastructure for stormwater and flood management. $J$. Environ. Manag. 2019, 246, 868-880. [CrossRef]

32. Schwerdorf, I.; Werker, H.; Waser, J. Der Kölner Weg der Überflutungsvorsorge, [Translation: The Cologne way of flood prevention]. Korresp. Wasserwirtsch. 2018, 11, 100-106.

33. Stadtentwässerungsbetriebe Köln. Starkregengefahrenkarte [Translation: Heavy Precipitation Hazard Map]. Available online: https: / / www.hw-karten.de/index.html?Module=Starkregen\# (accessed on 5 August 2020). 
34. Henschel, F. Umbau von zwei öffentlichen Platzflächen in Köln-Porz-Eil zu multifunktionalen Freiräumen mit Retentionsfunktion: Überflutungsbetrachtung, [Translation: Conversion of two public areas in Cologne-Porz-Eil into multifunctional open spaces with retention functions. Flood consideration]. 2018.

35. Förder Landschaftsarchitekten GmbH. Entwurf-Eiler Schützenplatz-Übersicht: Projekt: Neugestaltung Plätze in Köln-Eil, [Translation: Draft—Eiler Schützenplatz—overview. Project: Redesign of areas in Cologne-Eil]. 2018. Available online: https: / / ratsinformation.stadt-koeln.de/getfile.asp?id=698674\&type=do\&, (accessed on 23 February 2021).

36. Förder Landschaftsarchitekten GmbH. Umgestaltung multifunktionale Freiräume in Porz-Eil: Eiler Schützenplatz-Erläuterungsbericht, [Translation: Redesign of multifunctional open areas in Porz-Eil. Eiler Schützenplatz-explanatory report]. Available online: https: / / ratsinformation.stadt-koeln.de/getfile.asp?id=698675\&type=do\&, (accessed on 23 February 2021).

37. Kuckartz, U. Einführung in die Computergestützte Analyse Qualitativer Daten, [Translation: Introduction to the Computer-Aided Analysis of Qualitative Data], 3., Aktualis. Aufl.; VS, Verl. für Sozialwiss: Wiesbaden, Germany, 2010; ISBN 978-3-531-16661-2.

38. Jacobs, K.; Lebel, L.; Buizer, J.; Addams, L.; Matson, P.; McCullough, E.; Garden, P.; Saliba, G.; Finan, T. Linking knowledge with action in the pursuit of sustainable water-resources management. Proc. Natl. Acad. Sci. USA 2016, 113, 4591-4596. [CrossRef]

39. Röschel, L.; Davis, M.; Naumann, S. Integrating user preferences into urban green and blue infrastructure planning: Insights from Halle, Germany and Stockholm, Sweden. In The Sustainable City XIII., Proceedings of the SUSTAINABLE CITY 2019, Valencia, Spain, 1-3 October 2019; Mambretti, S., Miralles i Garcia, J.L., Eds.; WIT Press: Southampton, UK, 2019; pp. $233-244$. 